
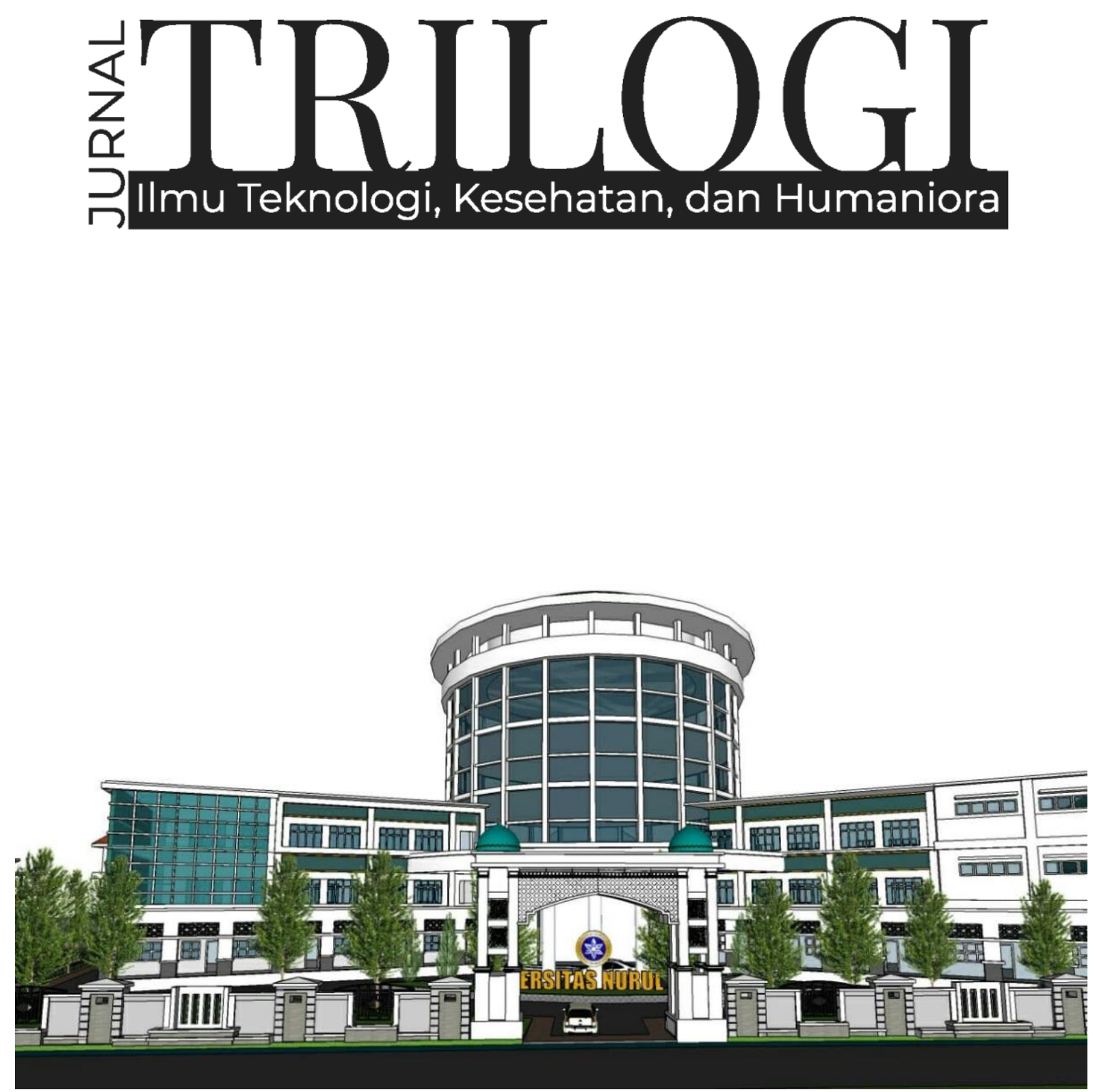

PENGEMBANGAN PENDIDIKAN DAN EKONOMI PESANTREN DI MASA PANDEMI COVID-19 


\section{犃BUOGI}

Vol. 2, No. 2, 2021

Editor in Chief

Achmad Fawaid, (SCOPUS ID: 57214837323)

\section{Managing Editors}

Hasan Baharun, (ID SCOPUS : 57200983602)

Sugiono Sugiono, (SCOPUS ID : 57199578160)

Ismail Marzuki, (SCOPUS ID: 57201500245

Subhan Rachman, (SCOPUS ID: 57192937912)

Nurul Huda, (SINTA ID: 6119615)

Syamsuri, (SINTA ID: 6116825)

Ridhatullah Assya'bani, (SINTA ID: 6200862)

\section{Peer Reviewers}

Miftahul Huda, (SINTA ID: 6171566), University of Antwerp, Belgium

Achmad Naufal Irsyadi, (SINTA ID: 6704870), Universitas Nurul Jadid, Indonesia

Gulpi Qorik Oktagalu P., (SINTA ID: 5982074) Universitas Nurul Jadid Probolinggo, Indonesia Hozairi, (SINTA ID: 166198), Universitas Islam Madura, Indonesia

Nur Hamid, (SINTA ID : 6744813), Univeristas Nurul Jadid Probolinggo, Indonesia Zainal Munir, (SINTA ID: 6672512), Universitas Nurul Jadid Probolinggo, Indonesia Sri Astutik Andayani, (SINTA ID: 6172559), Universitas Nurul Jadid Probolinggo, Indonesia Sukamto Sukamto, (SINTA ID: 5979034), Universitas Widya Gama Malang, Indonesia Deny Utomo, (SINTA ID: 6016108), Universitas Yudharta Pasuruan, Indonesia Fariz Alnizar, (SCOPUS ID: 6659824), UNUSIA Jakarta, Indonesia

Fuad Rahman, (SCOPUS ID: 57201474778), UIN Sulthan Thaha Saifuddin Jambi, Indonesia Saifuddin Zuhri Qudsy, (SCOPUS ID: 57213595165), UIN Sunan Kalijaga Yogyakarta, Indonesia Akhmad Anwar Dani, (SINTA ID: 14305), IAIN Surakarta, Indonesia

Maufur Maufur, (SINTA ID: 5989329), IAIN Kediri, Indonesia

Siti Mahmudah Noorhayati, (SINTA ID: 6726997), IAIN La Roiba Bogor, Indonesia Busro Busro, (SCOPUS ID: 57205022652), UIN Sunan Gunung Djati Bandung, Indonesia Akmal Mundiri, (SCOPUS ID: 57205059378), UNUJA Probolinggo, Indonesia

\section{Section Editor}

Ahmad Zubaidi, Universitas Nurul Jadid, Probolinggo, Indonesia 
TRILOGI: Jurnal IImu Teknologi, Kesehatan, dan Humaniora is a peer-reviewed journal, open-access journal which publishes original articles on various issues within technology, health, and social humanities, which include but are not limited to newrenewable energy, food-agriculture, health-pharmacy, transportation, informationcommunication technology, advanced-materials, maritime-infrastructre, social-artseducation, and religious studies based on academic and scientific research.

TRILOGI: Jurnal IImu Teknologi, Kesehatan, dan Humaniora seeks to publish a balanced mix of theoretical or empirical articles, case studies, review papers, comparative studies, exploratory papers, and book reviews. All accepted manuscripts will be possibly published both online and in printed forms.

Editorial Office:

TRILOGI: Jurnal IImu Teknologi, Kesehatan, dan Humaniora Lembaga Penerbitan, Penelitian, dan Pengabdian kepada Masyarakat (LP3M) Universitas Nurul Jadid, Paiton, Probolinggo, Jawa Timur, Indonesia 67291.

Phone: 088830 77077, Hp: 082318007953

Email: jurnal.trilogi@gmail.com

Website: https://ejournal.unuja.ac.id/index.php/trilogi/index 


\section{Tables of Content}

71-76

Pengaruh Metode Pembelajaran Daring dengan Aplikasi Google Classroom terhadap Hasil Belajar Siswa Madrasah Ibtidaiyah Nurul Mun'im Paiton Probolinggo

Feriska Listrianti, Lailatul Munawwaroh, Sayyidatul Arifa, Siti Aisyah

77-84

Inklusivitas dan Responsivitas Pesantren dalam Penanganan Pandemi Covid 19: Telaah Hidden Curriculum Pembelajaran di Pondok Pesantren Nurul Jadid

Zakiyah BZ, Uswatun Hasnah, Nafistur Rahmah

84-94

Integrasi Kurikulum Madrasah Diniyah dengan Lembaga Formal dalam Meningkatkan Mutu Lulusan di Sekolah Menengah Pertama (SMP) Nurul Jadid Paiton Probolinggo

Abdurrahman, Ika Fitri Anwar, Sofiya Mauliza, Nadya Afkarina

95-104

Some Issues on Time Deposit Financing: An Islamic Perspective on Mudharabah Agreement at Baitul Maal wa Tamwil (BMT) NU in Randuagung Lumajang

Saifuddin, Abdul Hafid, Hengki Wahyu Pratama

$105-110$

Analisis Pengembangan Potensi Ekonomi Keluarga melalui Unit Usaha Kapuk

Fahrudin, Iis Sa'diyah, Rizaldi Chandra Gunawan

111-117

Penguatan Ekonomi Pesantren melalui Pengembangan Ekonomi Masyarakat Pesisir: Pelajaran dari Pondok Pesantren Nurul Jadid Paiton Probolinggo

Achmad Febrianto, Muhammad Habibullah, Aksal Ilhamsyah

118-125

Prevensi Perilaku Konsumtif Persepektif Abraham Maslow dan Tri Logi Santri

Muhammad Syaiful Suib, Habibatur Rizkiyah, Fitria Nur Ain 
$126-136$

Manajemen Pengembangan Kurikulum Berorientasi pada Pembentukan Karakter

Moh Rifa'i, Fatimah Al Zahra, Abdurrahman Abdurrahman, Mukhlisin Saad

137-147

Home Industry, Kaderisasi, dan Santripreneur

Muh Hamzah, Aprilinda Dwi Kurniawati, Husnul Khotimah

148-157

Rancangan Pengelolaan Nirsampah Mandiri Skala Lembaga Pendidikan

Tirmidi, Eril Sinta Nuriyah, Rofi'ah

158-166

Parents' Knowledge and Commitment To Stimulate Child Development

Lailatul Fitriyah, Nurul Islamiyah, Auliya' Fatahillah

167-172

Implementasi Pembelajaran Akhlak Berbasis Multikultural pada Masa Pandemi di Madrasah Tsanawiyah Nurul Jadid Paiton Probolinggo

Abdullah, Yusrolana, Nur Laily

$173-183$

Implementasi Evaluasi Pembelajaran Daring (Online) melalui Home Visit

Moch Tohet, Moh. Bagus Abdillah, Adam Hakim Al Rizki

184-192

Efektivitas Pembelajaran Luring pada Mata Pelajaran Matematika selama Pandemi Covid-19

Zaenol Fajri, Sukron Junaidi, Hamdani Alfarisi 
P-ISSN: 2774-4574; E-ISSN: 2774-4582

TRILOGI, 2(2), Mei-Agustus 2021 (173-183) @2021 Lembaga Penerbitan, Penelitian, dan Pengabdian kepada Masyarakat (LP3M) Universitas Nurul Jadid Paiton Probolinggo

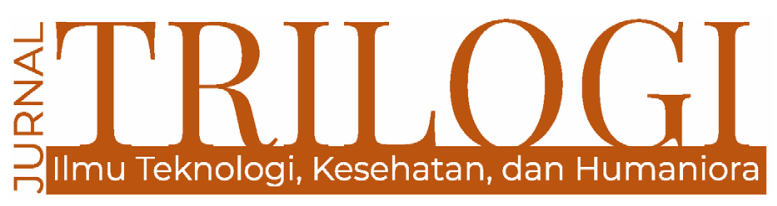

\title{
IMPLEMENTASI EVALUASI PEMBELAJARAN DARING (ONLINE) MELALUI HOME VISIT
}

\author{
Moch. Tohet \\ Universitas Nurul Jadid \\ elheds78@gmail.com \\ Moh. Bagus Abdillah \\ Universitas Nurul Jadid \\ bagusabdillah59@gmail.com
}

\section{Adam Hakim Al Rizki}

Universitas Nurul Jadid

adamhazky20@gmail.com

\begin{abstract}
.
This study aims to analyze the evaluation of online learning through home visit. The home visit is expected to build good relationships between the school, parents, and students concerned. The purpose of this Home Visit is to understand more in the environment of students everyday at home, and discuss their problems with their parents. This research was conducted at Madrasah Ibtidaiyah Nurul Mun'im, a formal educational institution for the elementary level of religion (elemetary school of religion). This location was chosen because this Madasah is at the location of the Islamic boarding school and under the auspices of the Nurul Jadid Paiton Probolinggo Foundation, where the students have mukim / lived in pesantren, and some lived at home together with their families. This situation raises a problem in conducting learning evaluations. This study uses qualitative methods, the data is obtained based on observation and researchers' participation, then obtained by a description of the data that has been obtained, then analyzed to obtain conclusions. The results showed that Mi Nurul Mun'im teachers experienced a slight trouble in conducting learning evaluations, the difficulty of assessing the indicators of the achievement of students, the difficulty of giving examples of honesty values, and also the lack of and some of the work factors of work from parents who made unable accompanying their son, also a lack of parental knowledge in using learning applications. By taking home visit, educators can provide solutions and can build good relationships with parents with the aim that the online learning process is possible to take.
\end{abstract}

Keywords: Learning Evaluation; Online Learning; Home Visit 


\begin{abstract}
Abstrak.
Penelitian ini bertujuan untuk menganalisis evaluasi pembelajaran daring melalui kunjungan rumah (home visit), yang diharapkan juga dapat membangun hubungan yang baik antara pihak sekolah, orang tua, dan peserta didik yang bersangkutan. Tujuan dari home visit ini adalah untuk memahami lebih dalam lingkungan peserta didik sehari-hari di rumah, dan mendiskusikan masalah mereka dengan orang tuanya. Penelitian ini dilakukan di Madarasah Ibtidaiyah Nurul Mun'im, lembaga pendidikan formal tingkat dasar berciri khas agama (setingkat SD). Lokasi ini dipilih karena memiliki daya tarik tersendiri, di antaranya karena madarasah ini berada di lokasi pondok pesantren dan di bawah naungan Yayasan Nurul Jadid Paiton Probolinggo, di mana peserta didiknya ada yang mukim/tinggal di pesantren, dan ada yang tinggal di rumah bersama dengan kelurganya, yang menimbulkan problemnya tersendiri dalam melakukan evaluasi. Penelitian ini menggunakan metode kualitatif, datanya diperoleh berdasarkan observasi dan keikutsertaan peneliti, kemudian dioleh dengan dilakukan deskripsi atas data yang sudah diperoleh, selanjutnya dianalisis untuk memperoleh kesimpulan. Hasil penelitian menunjukkan bahwa para guru MI Nurul Mun'im mengalami sedikit kesusahan dalam melakukan evaluasi pembelajaran, kesulitan menilai indikator pencapaian peserta didik, kesulitan memberikan contoh dari nilai-nilai kejujuran, dan juga kurangnya dan beberapa faktor kesibukan kerja dari orang tua yang membuat tidak mampu mendampingi anaknya, juga kurangnya pengetahuan orangtua dalam menggunakan aplikasi pembelajaran. Dengan adanya kunjungan rumah atau home visit pendidik dapat memberikan solusi dan dapat membangun hubungan yang baik dengan orang tua dengan tujuan agar proses pembelajaran daring dapat berjalan dengan maksimal.
\end{abstract}

Katakunci: evaluasi pembelajaran; pembelajaran online; home visit

\section{Pendahuluan}

Akibat pandemi COVID-19, dunia pendidikan berubah, bahkan memengaruhi seluruh aspek kehidupan manusia. Menurut Kementerian Kesehatan Republik Indonesia, Indonesia menjadi salah satu negara yang terkena dampak penyebaran virus COVID-19, dan seiring berjalannya waktu menjadi negara dengan kasus terbanyak di Asia. Pemerintah Indonesia sudah berupaya semaksimal mungkin untuk mencegah penyebaran virus COVID-19 dan memprediksi penyebaran virus tersebut. Pemerintah telah melakukan berbagai langkah seperti melakukan isolasi mandiri (isoman), menjaga jarak dalam kerumunan dan mengurangi kontak fisik sampai Pembatasan Sosial Berskala Besar (PSBB). (Nurmaya et al., 2021) Bahkan yang terbaru adalah dengan pelaksanaan Pemberlakukan pembatasan kegiatan Masyarakat (PPKM), baik level 1, 2, 3 bahkan 4.

Dalam Surat Edaran Menteri Pendidikan dan Kebudayaan Nomor 4 Tahun 2020 tentang Penerapan Kebijakan Pendidikan dalam mencegah penyebaran Corona Virus Disease 2019 (COVID19), dijelaskan bahwa proses pengajaran dilakukan di tingkatan sekolah akan dijalankan dengan pembelajaran online/jarak jauh di rumah. Bagi perguruan tinggi, sesuai dengan surat Kementerian Pendidikan dan Kebudayaan, mengatakan seluruh perguruan tinggi dapat menjalankan pembelajaran selama masa darurat pandemi COVID-9 dilakukan melalui berbagai bentuk kegiatan pembelajaran yang aktif dan positif baik dengan online dan offline. (Sun'iyah, 2020)

Pembelajaran online/daring yang dilaksanakan secara tiba-tiba menemui kendala, sehingga implementasinya belum berkembang secara optimal. Kendala yang ditemui di lapangan adalah kurangnya sarana dan prasarana yang memadai untuk mendukung pelaksanaannya, seperti tidak semua peserta didik memiliki kesempatan untuk mengikuti pembelajaran online, terutama pendidik yang belum menguasai betul teknologi secara mumpuni sehingga menjadi kendala tersendiri dalam pelaksanaannya. Semua kendala yang ditemukan di lapangan ini karena tidak dipersiapkan dengan baik sehingga berdampak terhadap pembelajaran online, yang dapat memengaruhi kualitas pendidikan baik secara sebagian, keseluruhannya. (H. Indonesia, 2020)

Pembelajaran online yang dilakukan di rumah memiliki kelebihan dalam pelaksanaannya, peserta didik dapat mengakses materi dan pekerjaan rumah (PR) yang diberikan oleh pendidik tanpa dibatasi oleh waktu dan tempat. Pembelajaran online memudahkan peserta didik untuk belajar sekaligus memaksimalkan pendidikan dan pengetahuan di masa pandemi. (Amalia, 2016)

Sejak dideklarasikannya Corona Virus Disease 2019 atau biasa disebut dengan Covid-19 sebagai 
wabah nasional pada 11 Maret 2020, model pembelajaran di seluruh institusi pendidikan baik tingkat dasar, menengah, atas, maupun di tingkat perguruan tinggi mulai melakukan adaptasi, di antaranya dengan melaksanakan model pembelajaran melalui sistem daring (dalam jaringan) atau online. Pembelajaran daring dilakukan sebagai pilihan stategis dalam memutus penyebaran wabah covid-19. Menteri Agama menegaskan bahwa penyelenggaraan pendidikan harus mempertimbangkan kesehatan dan keselamatan dengan memprioritaskan pelayanan pendidikan secara daring. (Yudiawan, 2020).

Wabah COVID-19 merupakan wabah yang berasal dari Tiongkok tepatnya dari kota Wuhan. Wabah ini menular dari manusia ke manusia lain dan telah menyebar ke lebih dari 190 negara. Dampak wabah ini telah mengakibatkan jutaan nyawa melayang di seluruh dunia, melumpuhkan berbagai bidang kehidupan, seperti ekonomi, sosial, dan pendidikan, dan lainnya.

Menurut pengakuan WHO pada bulan Maret tahun 2020 lalu COVID-19 adalah merupakan penyakit yang menyerang saluran pernafasan para penderitanya dan dapat menular dari sentuhan dan lewat udara. Penderita COVID-19 ini akan mengalami gangguan pernafasan ringan hingga sedang dan dapat sembuh tanpa perawatan intensif, kecuali untuk orang yang telah manula dan yang telah memiliki riwayat penyakit penyerta (komorbid), seperti pernapasan kronis, diabetes, dan lain-lain.

Pembelajaran jarak jauh yang dilakukan secara online membuat banyak sekali perubahan, baik dari segi metode pembelajaran maupun dari segi penilaian. Dalam hal itu tentu saja mengakibatkan pendidik dan peserta didik juga menghadapi banyak kendala. Selama menjalani proses pembelajaran jarak jauh, banyak dari para peserta didik yang mengalami kesulitan ketika melakukan pembelajaran secara online di antaranya yaitu dari akses internet yang kurang memadai, pemahaman materi yang kurang maksimal, dan susahnya melawan rasa malas.

Akses internet adalah merupakan salah satu permasalahan yang dihadapi banyak peserta didik dalam pembelajaran online. Salah satu faktornya adalah sinyal/jaringan yang tidak tersedia di berbagai daerah, terutama bagi pelajar di daerah terpencil, sinyal tersebut masih sulit didapatkan. Untuk rata-rata peserta didik sekolah menengah yang sudah memiliki smartphone, biaya menjadi masalah lain yang mengkhawatirkan, karena jika mereka tidak menggunakan fasilitas WiFi di rumah, para peserta didik harus mengeluarkan lebih banyak biaya untuk membeli kuota Internet.

Masalah tidak tersedianya kuota internet terjadi ketika orang tua peserta didik mengalami masalah pada ekonomi mereka, dan peserta didik kesulitan untuk membeli kuota Internet. Di samping itu, Proses pembelajaran online terkendala, jika sinyal/jaringan terputus karena cuaca buruk, sehingga peserta didik tidak akan bisa berkonsentrasi belajar karena hal tersebut dan lain sebagainya.

Akses internet yang terputus dapat mengganggu proses pembelajaran dan menyulitkan peserta didik dalam memahami materi. Jika peserta didik melakukan pembelajaran tatap muka saja mengalami kesulitan, apalagi belajar dengan sistem daring/online. Maka dari itu para peserta didik juga harus mengambil inisiatif untuk belajar sendiri secara mandiri dan mencari sumber lain di internet untuk meningkatkan pemahaman tentang materi yang dipelajari.

Dikutip dari medcom.id menjelaskan bahwa 1.700 peserta didik dengan pembelajaran jarak jauh yang telah di survey oleh Komisi Perlindungan Anak Indonesia (KPAI) hanya dalam empat minggu pertama sejak pembelajaran online dilaksanakan, ditemukan banyak peserta didik yang tidak puas dengan pengalaman belajar online. 76,7\% peserta didik menyatakan tidak suka belajar di rumah, dan 23,3\% mengatakan mereka puas dengan pembelajaran jarak jauh di rumah. (KPAI: Pembelajaran Jarak Jauh Minim Interaksi - Medcom. Id, n.d.)

Pembelajaran online justru meningkatkan rasa malas dan menyulitkan peserta didik untuk berkonsentrasi. Selain pekerjaan rumah (PR) tidak hanya membuat peserta didik pusing, tetapi mereka juga memiliki lebih banyak waktu untuk bermain dengan gadget. Misalnya, bermain game dan membuka jejaring sosial seperti Instagram, Twitter, dan YouTube. Akibatnya timbul rasa malas yang sulit diatasi saat belajar, sulit berkonsentrasi, apalagi guru sering memberikan banyak pekerjaan rumah (PR), yang justru membuat peserta didik merasa tambah bosan dan stres saat belajar.

Selain ketiga hal tersebut, banyak kendala lain yang dihadapi peserta didik dalam mengikuti proses pembelajaran online, tergantung dari situasi peserta didik dan daerah tempat tinggalnya (Kendala Belajar Online Bagi Siswa Saat Pandemi Covid-19 | Kumparan.Com, n.d.)

Dengan adanya wabah covid-19, memunculkan dampak yang signifikan terhadap semua aspek 
hidup seperti Kesehatan, ekonomi, sosial, terlebih di aspek pendidikan. Salah satunya adalah beralihnya model pembelajaran dari tatap muka menjadi pembelajaran daring yang dilakukan secara jarak jauh. Hal ini sesuai dengan Surat Edaran yang di keluarkan oleh Menteri Pendidikan dan Kebudayaan No. 4 tahun 2020 tentang pelaksanaan kebijakan pendidikan dalam masa darurat penyebaran Corona Virus Disease (Covid-19) yang memutuskan bahwa sejak tertanggal 24 Maret 2020 secara resmi proses pembelajaran di semua jenjang pendidikan melakukan proses pembelajaran jarak jauh melalui sistem pembelajaran daring yang dilaksanakan untuk memberikan pengalaman belajar yang bermakna bagi peserta didik, memberi pembelajaran kecakapan hidup, umpan balik yang bersifat kualitatif dan berguna dari guru. (Shofa, 2020).

Perubahan metode belajar yang semula tatap muka menjadi pembelajaran daring/online, tentu membawa perubahan yang signifikan dalam proses pembelajaran. Guru sebagai pengajar dan peserta didik harus beradaptasi dengan kendala-kendala yang mungkin akan muncul selama proses pembelajaran daring baik kendala yang disebebkan faktor internal maupun faktor eksternal (Astuti, 2020)

Implementasi pembelajaran daring/online di semua jenjang pendidikan khususnya di tingkat pendidikan dasar masih berat bagi sebagian pendidik, meskipun sebenarnya rata-rata pendidik sudah memiliki perangkat ponsel yang dapat digunakan untuk mengoperasikan media pembelajaran daring/online tersebut. Namun hal ini tidak mudah untuk menerapakannya, dikarenakan sebagian besar dari mereka kurang terbiasa dengan pembelajaran daring/online atau bahkan sebagian dari mereka masih kesulitan dalam mengoperasikan layanan internet di smartphone. Meskipun tidak bisa dipungkiri sebagian pendidik sudah memiliki akun sosial media yang merupakan bagian dari layanan internet melalui aplikasi online. Permasalahan yang sama juga di temukan dari kalangan anak-anak, yang sebagian besar masih belum memiliki smartphone pribadi ataupun ada sebagian dari mereka yang menggunakan smartphone milik anggota keluarganya, yang terkadang juga masih digunakan oleh keluarganya untuk kepentingannya. Namun sebagian dari mereka masih belum tahu cara mengoperasikan smartphone, meski anak-anak zaman sekarang sudah familiar terhadap teknologi dan perkembangannya, di karenakan sebagian dari mereka hanya menggunakan smartphonenya untuk kepentingan bermain game, sehingga penting bagi para pendidik dan keluarga mengarahkan fenomena tersebut menjadi hal yang positif untuk menunjang pendidikan mereka (Pembelajaran, n.d.).

Ada banyak permasalahan yang sering kita temui bagi peserta didik dalam mengikuti pembelajaran yang mengakibatkan mereka mengalami kesulitan dalam kegiatan belajar di sekolah ataupun permasalahan-permasalahan lain yang berasal dari dalam dirinya sendiri atau dari lingkungan luar peserta didik. Mengatasi kondisi yang seperti ini, berarti harus ada program dari layanan bimbingan dan konseling di SD/MI yang memiliki tugas penting dalam membantu peserta didik untuk mengatasi permasalahan yang timbul dalam proses pembelajaran di sekolah, atau membantu dalam menyelesaikan permasalahan yang dialami anak didik sehingga tidak merusak terhadap kualitas pembelajaran. (Minu et al., 2013).

Kualitas pembelajaran adalah pokok penting yang harus menjadi prioritas dalam perbaikan sistem pendidikan. Upaya yang dapat dilakukan untuk peningkatan kualitas tersebut adalah mengembangkan pembelajaran yang berorientasi pada peserta didik. Sistem pembelajaran bisa dibentuk agar peserta didik memiliki kemampuan untuk belajar secara interaktif, dan proses pembelajaran menjadi lebih menarik dan bervariasi. Kompetensi menjadi hak yang harus dimiliki oleh peserta didik dikarenakan kompetensi sangatlah berguna bagi masa depannya. Dengan semakin pesatnya perkembangan teknologi dan informasi serta infrastrukturnya, maka saat ini harus dimanfaatkan dalam upaya peningkatan kualitas pembelajaran. (Mulya, 2020).

Dan juga ada beberapa faktor yang memengaruhi kualitas dari proses pembelajaran itu sendiri fasilitas yang kurang memadai. Meskipun dapat dikatakan susah dalam mengevaluasi proses pembelajaran, namun begitu evaluasi harus tetap dilakukan walaupun tidaklah mudah karena evaluasi berperan sebagai tolak ukur dan menilai keberhasikan dari proses pembelajaran dan pencapaian dari seorang peserta didik terhadap beberapa sasaran dari sebuah pembelajaran. Sehingga hasil dari evaluasi dapat dijadikan sebagai materi dalam peningkatan dan kualitas dari sebuah proses pembelajaran.

Pendidik memberikan materi pembelajaran melalui aplikasi berbasis online atau daring, meskipun pada awalnya yang di alami bagi para tenaga pengajar mengalami adanya kesusahan 
dalam menjelaskan materi terlebih dalam pengawasan terhadap peserta didik atau dalam hal mengevaluasi para peserta didik karena pendidik tidak berada di ekat para peserta didik dan juga sulitnya para pendidik mengamalkan nilai dari kejujuran saat ujian yang dilakukan dirumah.

Permasalahan yang juga dihadapi saat melakukan pembelajaran daring/online di jenjang sekolah dasar adalah kurang maksimalnya kerja sama yang dilakukan oleh pendidik dan orang tua peserta didik sebagai perantara pembelajaran anak selama di rumah, dikarenakan para orang tua juga memiliki kesibukan dalam rumah tangganya. Ada berbagai kendala yang di hadapi oleh masing-masing orang tua peserta didik saat pembelajaran daring/online, di antaranya adalah di mulai dari manajemen waktu orang tua, tidak samanya kemampuan teknologi yang dimiliki tiap orang tua peserta didik khususnya dalam mengoperasikan smartphone, kebingungan dalam penyesuaian metode pembelajaran yang dilakukan oleh pendidik, cara penilaian pendidik terhadap hasil pembelajaran peserta didik setiap harinya dengan pembelajaran daring/online(Andini \& Widayanti, 2020). Tentunya dengan banyaknya permasalahan yang ditemukan saat penerapan pembelajaran daring /online mengharuskan maksimalnya pelaksanaan evaluasi pembelajaran.

Evaluasi pembelajaran merupakan komponen yang harus dilakukan oleh para pendidik, baik dari level terendah sampai dengan level tertinggi. Karena para pakar pendidikan mengungkapkan bahwa evaluasi pembelajaran merupakan alat yang dengannya bisa menjaring informasi untuk mengetahui ketercapaian kompetensi pembelajaran yang telah diterapkan dan ditetapkan sebelumnya, sebagai tolok ukur keberhasilan proses pelaksanaaan pembelajaran bagi pendidik (Nurzannah \& Setiawan, 2020).

Walaupun terbilang sulit dalam melaksanakan evaluasi pembelajaran yang dilakukan secara daring/online, akan tetapi harus tetap dilakukan evaluasi dalam sebuah pembelajaran. Karena Evaluasi berfungsi sebagai tolak ukur keberhasilan dalam proses pembelajaran. Evaluasi juga berfungsi untuk mengetahui sejauh mana pencapaian kompetensi peserta didik terhadap tujuan dari pembelajaran. Sehingga, dengan adanya evaluasi dapat dijadikan bahan pertimbangan saat melakukan perbaikan model pembelajaran dan peningkatan kualitas pembelajaran selanjutnya. (Damanik et al., 2020).

Beberapa permasalahan yang telah disebutkan di atas, sebenarnya juga menggambarkan apa yang terjadi di Madrasah Ibtidaiyah (MI) Nurul Mun'im Paiton Probolinggo. Problematika yang dihadapi oleh madrasah tersebut perihal evaluasi pembelajaran tentu memaksa para pendidik untuk memutar pikiran, mencari solusi pemecahan problematika evaluasi pembelajaran tersebut. Tentu dalam hal ini para pendidik harus pandai merancang model evaluasi pembelajaran alternatif dimasa pandemi Covid-19.

Tentunya dalam proses pembelajaran evaluasi merupakan bagian yang sangat penting. Dengan adanya evaluasi dapat memberi beberapa gambaran tentang bagaimana selama pembelajaran dari segi peningkatan penguasaan/daya serap peserta didik dalam proses pembelajaran dalam suatu materi begitupun dengan kesulitan yang peserta didik hadapi dalam materi yang lain.

Salah satu upaya yang dilakukan oleh MI Nurul Mun'im dalam mengatasi permasalahan di atas yakni dengan melakukan kegiatan home visit atau kunjungan ke rumah wali peserta didik oleh pendidik.

Home visit menurut bahasa dibagi menjadi dua kata, yaitu home yang berarti rumah, dan visit berarti kunjungan, mengunjungi, berkunjung (Nurdyansyah \& Nyong, 2020). Program home visit telah banyak dilakukan untuk memfasilitasi keluarga terutama pada keluarga kurang mampu dalam meningkatkan pemahaman mereka mengenai perkembangan dan kebutuhan anak. Dengan mengacu pada beragam manfaat dari program layanan home visit yang telah diteliti dan dilakukan oleh para ahli, serta berdasarkan permasalahan yang dialami oleh anak-anak usia dini yang hidup dalam kondisi beresiko pada keluarga pra sejahtera sehingga menyebabkan angka partisipasi yang rendah dalam pendidikan anak usia dini (KOMALASARI, 2016).

Home visit juga dilakukan untuk memperoleh kebenaran fakta dari beberapa informasi yang diperoleh. Melalui home visit, para pendidik dapat mengetahui secara jelas, bagaimana bentuk perhatian wali peserta didik yang dilakukan pada anaknya. Melalui jenis-jenis komunikasi atau bentuk komunikasi apa yang dilakukan oleh orang tua, yang memungkinkan bagi peserta didik memiliki motivasi belajar yang baik. Mereka juga memberikan pendampingan peran orang tua sebagai pendidik utama, sehingga tanggung jawab, pemberi motivasi dalam bentuk kasih sayang, orang tua memberi pengaruh dan arah terhadap anak-anak. Dengan adanya home visit ini diharapkan dapat membuat anak didik menjadi terbangun motivasi belajarnya. Jika 
motivasi belajar mereka sudah terbangun, nilai/ hasil pelajaran mereka pun akan menjadi lebih baik. (U. P. Indonesia, 2019).

Adapun dengan diadakannya evaluasi juga memiiki kelemahan dalam instrumennya, karena yang dipakai adalah evaluasi manual, diantaranya evaluasi manual ini memerlukan waktu dan uang yang cukup banyak untuk menjalankannya, juga lalu dalam hal proses pemeriksaan evaluasinya yang cukup rumit sehingga memerlukan waktu yang banyak juga dan cenderung membosankan, dan yang terakhir secara psikologis evaluasi manual ini sering menimbulkan rasa cemas pada peserta tes nya, karena pengawas yang berada di sekitar mereka dan kondisi lingkungan disekitarnya yang sering membuat rasa cemas. Sehingga kondisi seperti ini harus dapat diatasi. Perlu diciptakan proses evaluasi dalam mekanisme nya dipermudah semua.

Berdasarkan paparan di atas, penelitian tentang implementasi evaluasi pembelajaran (online) daring di MI NURUL MUN'IM merasa sanagt menarik untuk dilakukan. Adapun tujuan penelitian ini adalah (1) mengetahui alasan menggunakan evaluasi pembelajaran (online) daring; (2) mengetahui bagaimana persiapan evaluasi pembelajaran (online) daring; (3) mengetahui bagaimana sarana dan prasarana implementasi evaluasi pembelajaran (online) daring; (4) mengetahui bagaimana cara penerapan evaluasi pembelajaran (onlne) daring; (5) mengetahui apa kendala pada evaluasi pembelajaran (online) daring; (6) bagaimana mengatasi kendala pada evaluasi pembelajaran (online) daring.

\section{Metode}

Dalam penelitian ini metode yang digunakan adalah metode kualitatif studi kasus, yakni evaluasi pembelajaran daring/online di MI Nurul Mun'im Paiton Probolinggo dengan teknik observasi dan wawancara. Dengan menggunakan metode ini dapat diketahui kondisi riil yang ada di MI Nurul Mun'im. Dengan melakukan wawancara kepada pendidik untuk memperoleh informasi tentang kesulitan yang dihadapi oleh pendidik dalam mengevaluasi dan melakukan penilaian hasil pembelajaran peserta didik, dan juga dengan mewawancarai peserta didik untuk memperoleh informasi terkait kendala-kendala apa saja yang di alami ketika mengikuti pembelajaran daring di tengah pandemi Covid-19 dan motivasi belajar peserta didik dalam menghadpi situasi dan kondisi tak menentu.

Subjek penelitian ini adalah pendidik, peserta didik dan orang tua peserta didik MI Nurul Mun'im yang terlibat dalam pelaksanaan evaluasi pembelajaran online daring/online, yang diambil secara acak.

\section{Hasil dan Pembahasan}

\section{Hasil Wawancara}

Kepada para responden diajukan lima pertanyaan yang diharapkan dapat memberikan deskripsi pelaksanaan evaluasi pembelajaran online dg home visit serta kendala yang dihadapi para responden ketika mengikuti pembelajaran secara daring/online. Berikut ini adalah wawancara yang diajukan kepada responden beserta rangkuman jawaban yang diberikan.

Pertanyaan 1: Pada masa pandemi ini apa saja kendala yang dialami oleh bapak/ibu dalam proses pembelajaran berbasis daring/online?

Ketika diberikan pertanyaan ini, hampir seluruh responden menjawab terdapat kendala lambatnya jaringan internet di tempat tinggal mereka. Hal ini bisa dimaklumi sebab mayoritas responden berada di daerah pedesaan, di mana di tempat mereka jaringan internet tidak stabil, sehingga sering muncul kendala ketika mereka ingin mengirim tugasnya, jaringan yang terputus ketika mengikuti pembelajaran daring/online, dan sebagainya. Hanya sedikit responden yang tidak mengeluhkan masalah jaringan internet, khususnya mereka yang sudah memiliki jaringan internet yg stabil, seperti wifi. Hal ini terjadi karena pembelajaran berbasis daring/online di MI. Nurul Mun'im ini masih dalam tahap awal, di mana bagi yang belum terbiasa tentu akan menghadapi beberapa macam kendala.

Pertanyaan 2: Apa saja kendala yang pernah dialami selama pembelajaran daring/online dalam hal aplikasi yang dipergunakan?

Dari berbagai aplikasi yang digunakan, di MI Nurul Mun'im kebanyakan responden mengalami kendala ketika menggunakan aplikasi Whatsapp (WA). Sering kali peserta didik dinggap terlambat hadir karena tertumpuknya pesan di grup yang sudah disediakan untuk pembelajaran daring/ online ini, dan kebanyakan peserta didik tidak terlalu bisa mengekspresikan pendapatnya secara tepat karena tidak terbiasa dengan mengungkapkan pendapat melalu pesan suara di Whatsapp (WA) ketika diskusi di grup berlangsung, dan ada banyak peserta didik ketika telah mengganti materi pembelajaran daring 
/online yang berlangsung, peserta didik itu menanyakan lagi materi sebelumnya yang sudah selesai dibahas, jadi pendidik mengalami kendala dalam menghadapi hal seperti ini karena akan mengalami kerumitan jika harus dijelaskan lagi lewat chat grup, sedangkan yang sedang dibahas ketika itu materi pelajaran yang baru.

Adapun beberapa peserta didik yang orang tua nya tidak memiliki smartphone atau telepon cerdas harus bergabung atau mengampung ke rumah teman dekatnya untuk bisa mengikuti pembelajaran daring/online ini. Hal ini juga menjadi kendala tersendiri, sebab mereka yang mengampung memiliki keterbatasan menggunakan fasiltas smartphone, yang berakibat pada keterbatasan akses materi pelajaran yang disampaikan.

Pertanyaan 3: Apa saja kendala yang pernah dialami selama pembelajaran online dalam hal cara penyampaian/penjelasan materi pembelajaran oleh pendidik?

Ketika diberikan pertanyaan ini, seluruh responden mengeluhkan kurang lancarnya komunikasi antara pendidik dengan peserta didik. Kebanyakan pendidik hanya memberikan bahan ajar melalui Whatsapp grup, dan jika ada pertanyaan disampaikan melalui kolom komentar yang berakibat pada kurang efektifnya proses pembelajaran. Selain itu ada pula pendidik yang hanya memberikan tugas dalam setiap pertemuan tanpa memberikan penjelasan mengenai materi/ topik pelajaran. Peserta didik dituntut untuk belajar sendiri, dengan hanya memberikan bahan ajar/modul, sedangkan bahan ajar/modul tersebut juga banyak yang dianggap sulit untuk dipahami.

Pertanyaan 4: Apa saja kendala yang pernah dialami selama pembelajaran online dari segi dukungan orang tua?

Responden menjawab mendapat dukungan penuh dari orangtua masing-masing sehingga tidak memiliki kendala dalam hal ini.

Pertanyaan 5: Apa saja kendala yang pernah dialami selama pembelajaran online dalam kaitannya dengan ekonomi keluarga?

Sebagian responden tidak memiliki kendala dalam hal ini, namun sebagian lagi mengeluhkan bertambahnya biaya paket internet yang harus dikeluarkan setiap bulannya, sementara penghasilan keluarga menetap bahkan cenderung menurun di masa pandemi ini, dan juga tidak meratanya bantuan dana paket internet kepada setiap peserta didik, maka dari itu ada beberapa peserta didik yang ketika pembelajaran daring/ online dimulai dia datang ke sekolah untuk bertemu langsung dengan pendidik yang sedang melaksanakan tugas menyampaikan materi mata pelajaran itu secara tatap muka, dan kadang meminta bantuan kepada beberapa pendidik ketika tertinggal materi karena tidak pahamnya beberapa penjelasan yang disampaikan secara daring/online.

Pertanyaan 6: Bagaimana implementasi evaluasi pembelajaran daring/online melalui home visit yang dilakukan dan apa manfaat yang didapatkan baik oleh peserta didik, pendidik, dan orang tua peserta didik?

Hasil penelitian yang dilakukan menunjukkan bahwa evaluasi pembelajaran melalui home visit dilakukan oleh pendidik dengan mendatangai rumah peserta didik. Pada saaat mendatangi rumah peserta didik terjadi inetraksi yang aktif antara pendidik, peserta didik dan orang tuanya. Hal yang dilakukan oleh dimulai dengan memeriksa kelengkapan buku beserta catatannya sesuai materi yang telah disampaikan oleh pendidik, baik buku paket atau pun buku lembar kerja harian. Setelah dilakukan pemeriksaan buku, selanjutnya dilakukan evaluai dengan memberikan tes, baik tulis dan/ lisan. Setelah dilakukan tes ini, pendidik melakukan wawancara kepada peserta didik dan orang tuanya. Wawancara ini dilakuakn untuk memperoleh informasi tentang aktifitas peserta didik ketika belajar daring/online, pendampingan dan pengawasan yang dilakukan oleh orang tua saat proses pembelajaran daring/online berlangsung, dan pendampingan belajara mandiri di luar waktu belajar daring/online yang telah dilaksnakan sesuai jadwal yang telah ditentukan oleh madrasah.

\section{Pembahasan}

Dari hasil wawancara dari para responden, terlihat bahwa pada umumnya kendala yang mereka alami bersifat mendasar atau antara lain kendala dalam hal jaringan internet dan juga kendala dalam hal pelayanan yang diberikan beberapa pendidik kepada peserta didik. Kendala utama yang dihadapi narasumber adalah masalah internet. Di daerah perkotaan, ada banyak ISP dengan kemampuan Internet yang sesuai untuk mendukung pembelajaran daring/online. Namun, di daerah pedesaan, hanya tersedia beberapa pilihan akses internet yang masih sedikit, dan kualitasnya dianggap kurang memadai sehingga kurang efektif dalam pelaksanaan pembelajaran daring/online. Hasil penelitian menunjukkan bahwa sebagian besar responden mengeluhkan kualitas Internet dan mahalnya biaya membeli 
kuota internet. Salah satu keputusan yang dapat mereka ambil untuk mengatasi masalah kurangnya akses internet adalah mendatangi langsung ke pendidik yang sedang mengajar daring/online yang dilakukan oleh beberapa anak yang jaraknya cukup dekat antara rumah dan sekolahnya. Sebab, pendidik yang memiliki jam mengajar datang ke sekolah, sebab sekolah menyedikan fasilitas pembelajaran daring/online bagi mereka. Kendala berikutnya yang mereka keluhkan adalah cara pendidik memerikan materi pelajaran. Karena belum terbiasa memberikan pembelajaran secara daring/online, maka pola komunikasi saat pembelajaran cenderung searah, sehingga pendidik kadang tidak memedulikan apakah materi yang sduah disampaikan dipahami dan diserap oleh para peserta didik.

Sebagian peserta didik menganngap bawa pembelajaran dengan cara seperti ini tidak dapat memberikan pemahaman yang utuh kepada mereka. Mereka seringkali mengalami kebuntuan ketika mempelajari mata pelajaran yang tidak terlalu dipahaminya, namun mereka hanya bisa bertanya melalui fitur chat di grup Whatsapp. Beberapa peserta didik menganggap hal ini belum maksimal karena penjelasan pendidik dalam chat atau komentar kelompok sulit dipahami dan terbatas dalam penyampaiannya.

pendidik juga jarang melakukan pembelajaran daring/online melalui aplikasi video conference semisal zoom, google meet atau classroom. Untuk mengatasi kendala pemahaman materi pembelajaran secara daring/online, peserta didik dapat membuka website atau youtube yang menjelaskan topik yang dipelajarinya. Dengan cara ini, mereka dapat memahami penjelasan orang lain selain pendidik. Hal ini dipandang sebagai salah satu kendala dan kekurangan pembelajaran online yang mereka ikuti.

Penelitian ini juga menghasilkan kesimpulan bahwa hambatan belajar online yang dihadapi peserta didik masih termasuk dalam kategori paling dasar. Hal ini seharusnya menjadi salah satu hal yang perlu diperhatikan dalam mempersiapkan dan melaksanakan pembelajaran secara daring/online.

Selama pandemi Covid19, pendidik sebagai pendidik dan pengajar menghadapi banyak hambatan dalam pembelajaran daring/online. Karena adanya pandemi, pembelajaran yang semula tatap muka (offline/luring) kini lebih banyak dilakukan secara daring/online. Terdapat kendala dalam pembelajaran online, seperti: (1) tempat tinggal yang belum terjangkau internet, termasuk biaya internet yang cenderung mahal bagi peserta didik, (2) bahan ajar yang digunakan pendidik sebagian besar membosankan bagi peserta didik, (3) pembelajaran dominan belum interaktif, karena cendenrung searah, (4) karakter atau perilaku peserta didik sulit dipantau, (5) pembelajaran biasanya berupa tugas online, (6) tugas peserta didik yang menumpuk menjadi kendala lain, dan (7) tingkat penyerapan materi sangat rendah. Sebagai seorang pendidik, perlu menemukan solusi yang tepat untuk mengatasi hambatan ini.

Dengan pelaksanaan evaluasi pembelajaran online melalui home visit, pendidik sebagai wakil madrasah dapat mengetahui tingkat keaktifan anak dan permasalahan-permasalahan yang terjadi di luar lingkungan sekolah serta tawaran pemecahannya.

Dengan home visit, pendidik juga dapat mengetahui informasi-informasi yang berkaitan dangan kehidupannya, khususnya latar belakang orang tua dan peserta didik, baik aspek ekonomi, sosial, budanya, perilaku keagamaannya, dan lainnya.

Hal ini penting diketahui oleh pendidik agar dapat menentukan metode, model, dan strategi pembelajaran yang akan ditempuh di waktu selanjutnya.

Dalam rangka memberikan motivasi belajar kepada peserta didik, perlu dilakukan kerjasama dengan melibatkan oarng tua dan keluarga peserta didk. Oleh sebab itu, kerjasama yang terjalin baik antara pendidikan dan orang tua peserta didik mutlak sangat diperlukan. Dengan adanya hubungan yang baik antara pendidik dengan orang tua peserta didik, akan berakibat kepada terbentuknya komunikasi dan inten dan pengawasan pada pserta didik dari dua arah, baik dari pendidik dan orang tua peserta didik.

Kegiatan visit home juga menjadi media yang sangat baik untuk menyampaikan visi dan misi madarasah kepada pendidik dan orang tuanya. $\mathrm{Hal}$ ini sangat perlu dilakukan agar orang tua juga berperan untuk melakukan menciptakan iklim belajara bagi anaknya guna mencapai visi dan misi madsarah yang telah ditetapkan.

Pada masa pendemi, kegiatan home visit sangat perlu dilakukan karena sangat berguna. Hal ini terjadi karena rumah adalah tempat berkembanganya kepribadian peserta didik dalam durasi waktu yang lebih lama bila dibandingan dengan waktu belajar sesuia jadwal madrasah. Pendidikan dan orang tua dapat melakukan komunikasi yang aktif dan inten untuk koordinasi berkaitan dengan 
pembinaan pembentukan dan perkembangan karakter peserta didik serta menawarkan solusisolusi dalam menyelesaikan segara permasalahan yang dihadapi oleh peserta didik. Kesusksesan pendidikan dan pengasuhan serta petumbuhan peserta didik tidak luput dari kolaborasi antara pendidik, orang tua, dan masyarakat di mana peserta didik itu hidup.

Ada pun beberapa tawaran solusi yang dapat dilakukan yakni: (1) untuk lingkungan yang tidak terjangkau internet untuk pindah sementara ke lokasi yang terjangkau Internet. (2) upaya yang kedua dengan menggunakan berbagai media interaktif online, seperti aplikasi zoom, google meet atau classroom. (3) Saat menggunakan media online yang dapat disiarkan secara langsung, seperti menggunakan aplikasi zoom, google meet, dll. akan lebih mudah untuk memantau kepribadian atau perilaku peserta didik.

4) Materi yang merupakan bagian dari pengajaran harus diberikan kepada peserta didik untuk dibaca sehari sebelumnya. Saat pendidik menjelaskan materi, peserta didik dapat bisa lebih memahami apakah masih ada kesulitan dan bisa bertanya. Tugas yang diberikan memiliki batas waktu untuk dikumpulkan dan dinilai.

(5) Belum terlambat untuk mengerjakan pekerjaan rumah (PR). Setelah menerima tugas $(P R)$, segera koreksi/tandai, dan segera komunikasikan hasilnya kepada peserta didik. Akan lebih baik jika melibatkan orang tua/wali peserta didik dalam penilaian, mereka dapat membantumengawasi anaknya dengan baik di rumah masing-masing.

Penelitian di MI Nurul Mun'im ini juga menghasilkan beberapa poin yang yang penting untuk disampaikan dikarenakan penyebaran virus Covid-19 ini membuat proses pembelajaran dilakukan secara daring/online yang membuat sulitnya para pendidik untuk melakukan evaluasi dan penilaian terhadap proses maupun hasil pembelajaran terhadap peserta didik. Meskipun sulit dalam mengevaluasi pembelajaran peserta didik karena sistem pembelajarannya dilakukan secara daring/online, masih banyak cara dalam melakukan evaluasi peserta didik salah satunya yaitu dengan melakukan home visit atau kunjungan rumah.

Hasil dari penelitian berikutnya para pendidik bisa mengetahui masalah dari peserta didik yang terjadi dari luar linngkungan sekolah karena adanya kerjasama antara wali peserta didik dengan para pendidik melakukan home visit atau kunjungan rumah.
Karena dilihat dari kondisi pandemi ini proses pembelajaran tidak dapat dijalankan dengan maksimal disebabkan karena terbatasnya waktu dan jalan dari pembelajaran termasuk kurangnya sarana prasarana penunjang pembelajaran yang dimiliki oleh seorang peserta didik yang tidak memiliki smartphone, tetapi pendidik di MI Nurul Mun'in tidak boleh kehabisan cara untuk melaksanakan proses pembelajaran bagi peserta didik yang tidak memilki smartphone dengan memberlakukan pembelajaran tatap muka di sekolah dengan menerapkan protokol kesehatan yang sangat ketat, dengan menjaga jarak dan memakai masker, mencuci tangan dengan air yang mengalir, mamkai hand sanitizaer, dan tidak berjabat tangan, supaya peserta didik dapa terjaga dari covid-19.

Hasil dari evaluasi home visit yang peneliti temukan dari MI Nurul Mun'im adalah para pengajar di MI Nurul Mun'im melakukan penilaian tentang kelengkapan \& manfaat dan komitmen orangtua peserta didik pada menangani masalah belajar peserta didik baik dirumah juga di sekolah. Oleh karenanya pendidik menaruh solusi tentang kelebihan \& kekurangan menurut masing-masing peserta didik mengenai keefektifan evaluasi mengenai layanan pada proses penilaian yang diberikan oleh pendidik.

Kemudian setelah pendidik mengunjungi peserta didik di rumah, dan pendidik menemukan bahwa mereka memiliki masalah belajar di rumah dan di sekolah, dan pendidik memulai memecahkan masalah tersebut. Hasil kunjungan tersebut tidak hanya dapat membantu memecahkan masalah, tetapi juga sebagai alat untuk memotivasi peserta didik. Setelah pendidik mengunjungi rumah peserta didik, para pendidik menindak lanjuti masalah-masalah yang ditemukan pada saat mengunjungi rumah peserta didik dengan membuat masalah-masalah yang ditemukan tersebut sebagai bahan evaluasi untuk selanjutnya sebagai solusi dalam menghadapi masalahmasalah pada peserta didik.

Dari hasil observasi lingkungan oleh peneliti dapat disimpulkan bahwa para peserta didik yang tinggal di desa memiliki kebiasaan bermain setelah sepulang sekolah dan bermain game online, oleh karena itu pendidik menindaki masalah tersebut dengan menghubungi orang tua peserta didik atau dengan menghubungi peserta didik tersebut dengan menelepon, pesan whatsapp atau dengan pesan teks singkat jika orangtua sibuk dengan pekerjaan diluar rumah.

Kejujuran juga merupakan salah satu masalah 
yang dialami oleh peserta didik saat melakukan proses pembelajaran, karena proses pembelajaran dilakukan secara jarak jauh atau dengan kata lain pendidik dan peserta didik tidak bertatap muka secara langsung di kelas, maka kemungkinan peserta didik melakukan hal-hal yang tidak ada sangkut pautnya dengan proses pembelajaran seperti bermain game sosial media pada saat proses pembelajaran berlangsung. Maka akan sangat dibutuhkan peran yang sangat penting oleh orang tua peserta didik untuk selalu mendampingi dan mengontrol tindakan anak di saat belajar secara daring/online di rumah.

Sementara pelaksanaan pembelajaran MI Nurul Mun'im dimulai dengan melakukan persiapan yang dilakukan oleh pendidik dengan membuat perangkat pembelajaran. Persiapan pendidik berupa penetapan jadwal yang disusun berdasarkan tema tidak lagi disusun berdasarkan mata pelajaran.

Penyusunan jadwal mengikuti model jadwal pelajaran secara terintegrasi. Untuk mendukung penyampaian materi pada saat pelaksanaan pembelajaran, pendidik juga menyiapkan media pembelajaran yang akan digunakan dalam pembelajaran.

Pengelolaan kelas yang dilakukan pendidikn juga berpengaruh dalam pembelajaran, sehingga peserta didik tetap fokus pada pembelajaran yang sedang dilaksanakan.

Selain untuk mengenal tentang pemahaman peserta didik, evaluasi dari hasil belajar juga digunakan sebagai bahan untuk laporan kemajuan peserta didik yang akan dibagikan kepada orang tua peserta didik. Penilaian pendidik terhadap hasil belajar untuk menentukan topik hasil belajar, antara lain pada ujian akhir tertulis, ujian tengah semester (UTS) dan ujian akhir semester (UAS). Selain tes tertulis, pendidik juga akan mengamati perilaku dan aktivitas peserta didik dalam proses pembelajaran. Proses evaluasi dilakukan oleh pendidik dengan menggunakan metode observasi. Situasi belajar, partisipasi peserta didik, semangat dan daya juang peserta didik menguasai atau menggunakan buku ajar khusus. Setelah selesai pembelajaran, pendidik bertanggung jawab atas tindak lanjut pekerjaan peserta didik, yaitu merangkum semua materi yang disampaikan, memberi penghargaan kepada peserta didik yang aktif mengikuti pembelajaran, atau menghukum peserta didik yang ribut dalam belajar, dan memberikan tugas yang dapat dipajang peserta didik di kelas dan tugas yang dikerjakan rumah atau pekerjaan rumah (PR).
Faktor-faktor pendukung pelaksanaan pembelajaran di MI Nurul Mun'im dapat ditinjau dari beberapa hal yaitu: manajemen sekolah yang baik sangat mendukung pelaksanaan pembelajaran seperti dalam pembuatan jadwal pelajaran yang disesuaikan dengan waktu dan jam yang telah ditentukan oleh sekolah; dukungan Kepala Sekolah, Kepala Sekolah sangat mendukung pelaksanaan pembelajaran dengan memberikan kesempatan pendidik mengikuti berbagai pelatihan mengenai pembelajaran, dukungan pendidik lain, dalam pelaksanaan pembelajaran, dukungan dari sumber daya yang memadai dari pendidik itu sendiri. Pendidik dengan berbagai pengalaman mengajar dan inovasi dalam melaksanakan pembelajaran sangat mendukung terlaksanakannya pembelajaran yang efektif dan efesien.

\section{Kesimpulan}

Dari hasil analisis yang peneliti peroleh, dapat ditarik kesimpulan tentang pelaksanaan pembelajaran online, partisipasi peserta didik dalam mengikuti pembelajaran online, aplikasi yang digunakan dalam pembelajaran online, kondisi kualitas jaringan dalam proses pembelajaran online, dan kualitas materi yang diberikan pendidik selama pembelajaran online, waktu diskusi antara pendidik dan peserta didik selama pembelajaran online. Peneliti menemukan poin lain berdasarkan pandangan narasumber tentang pelaksanaan pembelajaran di semester berikutnya, yang menunjukkan bahwa mereka belum siap. pembelajran di masa pandemi Covid19 termasuk kategori yang baik, namun masih banyak hal yang perlu diputuskan dan diverifikasi sebelum lingkungan pembelajaran bisa kembali normal.

Penelitian yang dilakukan di MI Nurul Mun'im yang memberikan hasil yaitu para pendidik di MI Nurul Mun'im mengalami sedikit kesusahan dalam melakukan evaluasi pembelajaran, sulitnya menilai indicator pencapaian peserta didik, sulitnya memberikan contoh dari nilai-nilai kejujuran, dan juga kurangnya dan beberapa faktor kesibukan kerja dari orang tua yang membuat tidak mampu mendampingi anaknya, juga kurangnya pengetahuan orangtua dalam menggunakan aplikasi pembelajaran.

Dengan adanya kunjungan rumah atau home visit pendidik dapat memberikan solusi dan dapat membangun hubungan yang baik dengan orang tua dengan tujuan agar proses pembelajaran 
daring dapat berjalan dengan maksimal.

Kendala yang dihadapi peserta didik dalam proses pembelajaran (online) daring merupakan kendala-kendala yang harus dihadapi, diantaranya kendala di bidang jaringan internet, keterbatasan aplikasi pembelajaran (online) daring, serta kendala dalam hal penyampaian pembelajaran (online) daring. Kendala-kendala ini seharusnya menjadi perhatian dalam mempersiapkan dan melaksanakan pembelajaran (online) daring.

\section{Referensi}

Amalia, H. (2016). Implementasi Home Visit dalam Upaya Meningkatkan Pembelajaran PAI di SDIT al-Azhar Kediri. Didaktika Religia, 4(1), 77-106. https://doi.org/10.30762/ didaktika.v4.i1.p77-106.2016

Andini, Y. T., \& Widayanti, M. D. (2020). Pelaksanaan Pembelajaran Daring Pada Masa Pandemi Covid-19 Di Tk Bias Yogyakarta. Tarbiyatuna : Kajian Pendidikan Islam, 4(2), 206. https://doi. org/10.29062/tarbiyatuna.v4i2.424

Astuti, L. D. (2020). The POTRET EVALUASI PEMBELAJARAN DARING (E-LEARNING) MAHASISWA KESEHATAN DIMASA PANDEMI COVID-19. Jurnal Kebidanan, 9(2), 25-33. https://doi.org/10.47560/keb.v9i2.246

Damanik, S., Zuhdi, M., \& Herlina, H. (2020). Model Evaluasi Pembelajaran AUD Berbasis Daring di RA Nurun Namirah Medan Marelan (Studi Kasus Selama Masa Pandemi Covid-19). Al-Fatih: Jurnal Pendidikan Dan Keislaman, 3(1), 157.

Indonesia, H. (2020). Respon pada Pembelajaran Daring bagi Mahasiswa Mata Kuliah Pengantar Hukum Indonesia. 31(1).

Indonesia, U. P. (2019). MODEL PENDAMPINGAN KELUARGA BERBASIS ASESMEN, KONSELING , HOME VISIT DAN INTERVENSI SEBAGAI UPAYA MENUMBUHKAN MOTIVASI BELAJAR ANAK JALANAN DI YAYASAN RUMAH KITA ( eRKa ) CIPINANG JAKARTA. 31(1), 9-27.

Kendala Belajar Online bagi Siswa saat Pandemi Covid-19 | kumparan.com. (n.d.).

KOMALASARI, E. (2016). Layanan Home Visit Pendidikan Anak Usia Dini Bagi Anak Kurang Sejahtera. Ta'dib, 18(1), 76. https://doi. org/10.31958/jt.v18i1.280

KPAI: Pembelajaran Jarak Jauh Minim Interaksi - Medcom.id. (n.d.).
Lely Nurmaya, A. G., Ayu Lestari, A., \& Melani, F. (2021). Analisis Evaluasi Pembelajaran Daring (Online) Sekolah Dasar Selama Pandemi Covid 19. JKPD) Jurnal Kajian Pendidikan Dasar, 6(1), 80-85.

Minu, D. I., Putri, T., \& Roesminingsih, E. (2013). Rizma Bighum Halida Ziah, Implementasi Program Home Visit dalam Optimalisasi Hasil Belajar di MINU Trate Putri Gresik. $1-12$.

Mulya, R. (2020). EVALUASI PEMBELAJARAN ONLINE BERBASIS MOODLE. 18(1), 39-49. https://doi.org/10.31571/edukasi. v18i1.1653

Nurdyansyah, N., \& Nyong, E. (2020). Implementation of Home Visite Program in Overcoming Student Learning Problems in SD Muhammadiyah 1 Pucanganom Sidoarjo. Proceeding of The ICECRS, 6, $1-11$.

Nurzannah, \& Setiawan, H. R. (2020). Program Kemitraan Masyarakat Di Tengah Pandemi Covid-19 Bagi Guru Sd (Pembuatan Media Evaluasi Pembelajaran Online). Journal of Character Education Society, 3(2), 299-310.

Pembelajaran, M. E. (n.d.). MEDIA PEMBELAJARAN DARING BERORIENTASI EVALUASI. 1-18.

Shofa, M. F. (2020). Inovasi pembelajaran pada pendidikan anak usia dini di masa pandemi covid-19. Buana Gender, 5(2), 85-96.

Sun'iyah, S. L. (2020). Media Pembelajaran Daring Berorientasi Evaluasi. Jurnal Studi Keagamaan, Pendidikan Dan Humaniora, $7(1), 1-18$.

Yudiawan, A. (2020). BELAJAR BERSAMA COVID 19: Evaluasi Pembelajaran Daring Era Pandemi di Perguruan Tinggi Keagamaan Islam Negeri, Papua Barat. AL-FIKR: Jurnal Pendidikan Islam, 6(1), 10-16. https://doi. org/10.32489/alfikr.v6i1.64

Trianto. 2007. Model Pembelajaran Terpadu dalam Teori dan Praktek. Jakarta: Prestasi Pustaka Setyosari, P. \& Widijoto, H. 2007. Metode Penelitian Pendidikan. Malang: FIP Universitas Negeri Malang.

Trianto. 2010. Mengembangkan Model Pembelajaran Tematik. Jakarta: Prestasi Pustaka 